\title{
The Effect of Color Type and Light Intensity of Light Emitting Diode (LED) Light Traps on the Types and Number of Pest Insect Catches in Rice Plantations
}

\author{
Iqbal Erdiansyah*, Moch. Syarief dan Moch. Irfan Kusairi \\ ${ }^{1}$ Jurusan Produksi Pertanian, Politeknik Negeri Jember \\ *Corresponding Author : iqbal@polije.ac.id
}

Received July 12, 2020; revised December 28, 2020; accepted April 19, 2021

\begin{abstract}
The purpose of this study was to examine the effect of the type of color and light intensity of the light emitting diode (LED) Light traps on the type and number of insect pests in rice plantations. The research was conducted from November 2017 to March 2018, in Kencong Village, Jember Regency. The data collection method used Scan sampling, for 11 weeks, one week interval, starting at 07.00 p.m. to 04.00.a.m. The number of plots was 4 pieces, each $100 \mathrm{~m} 2$. The distance between the plots is 100 meters. Light traps in each plot, red, yellow, blue and white. Each color consists of 4 light intensities, namely 3 watts, 5 watts, 7 watts and 9 watts. Observation parameters: types and number of insect pests catches. The different types and numbers of insect pests caught were using the Kruskal-Wallis test. The normality of the data used the Shapiro-Wilt test. Statistical significance $\mathrm{p}<0.05$. Correlation between lamp color and light intensity, using the Spearman correlation test. Data were analyzed using SPSS version 23.0. The conclusions of the study were: The types of insect pests at various colors and intensity of LED light traps showed similarities, consisting of 5 orders, 6 families and 6 species. The red LED trap light indicates the highest number of pest catches. The number of insect pest catches of red LED was 475 individuals. A light intensity of 9 Watts indicates the highest number of insect pest catcheswere 568 individuals. The spearman correlation coefficient between the type of LED color and the light intensity $(r)=-0.415$.
\end{abstract}

Keywords: type; the number of rice insects pests catches; LED Light traps

\section{ABSTRAK}

Pengaruh Jenis Warna dan Intensitas Cahaya Lampu Perangkap Light Emitting Diode (LED) terhadap Jenis dan Jumlah Tangkapan Serangga Hama pada Pertanaman Padi

Tujuan penelitian ini adalah mengkaji pengaruh jenis warna dan intensitas cahaya lampu perangkap light emitting diode (LED) terhadap jenis dan jumlah tangkapan serangga hama pada pertanaman padi. Penelitian dilaksanakan pada November 2017 sampai Maret 2018, di Desa Kencong, Kabupaten Jember. Metode pengambilan data menggunakan Scan sampling, selama 11 minggu, interval satu minggu, dimulai jam 19.00 sampai 04.00. Jumlah plot 4 buah, masing-masing $100 \mathrm{~m} 2$, jarak antar plot 100 meter. Perangkap lampu di tiap plot, berwarna merah, kuning, biru dan putih. Tiap warna terdiri atas 4 intensitas cahaya yaitu 3 watt, 5 watt, 7 watt dan 9 watt. Parameter pengamatan: jenis dan jumlah tangkapan serangga hama. Perbedaan jenis dan jumlah tangkapan serangga hama menggunakan uji Kruskal-Wallis. Normalitas data menggunakan uji Shapiro-Wilt. Signifikansi statistik p <0,05. Korelasi antara warna lampu dengan intensitas cahaya, menggunakan uji korelasi Spearman. Data dianalisis menggunakan SPSS versi 23.0. Kesimpulan penelitian adalah: Jenis serangga hama pada berbagai warna dan intensitas cahaya lampu perangkap LED menunjukkan kesamaan, terdiri atas 5 ordo, 6 famili dan 6 spesies. Lampu perangkap LED warna merah menunjukkan jumlah tangkapan hama paling tinggi yaitu 475 ekor. Intensitas cahaya 9 Watt menunjukkan jumlah tangkapan paling tinggi yaitu 568 ekor. Koefisien korelasi spearman antara jenis warna lampu dan intensitas cahaya yaitu $(r)=-0,415$.

Kata Kunci: jenis, jumlah tangkapan serangga hama padi, lampu perangkap LED

\section{PENDAHULUAN}

Padi (Oryza sativa L.) adalah tanaman pangan yang memegang peranan penting dalam kehidupan manusia. Salah-satu kendala budidaya tanaman padi adalah hama yang aktif di malam hari dan tertarik dengan cahaya. Alat pemantauan hama yang efektif, ekonomis dan ramah lingkungan sekaligus berfungsi sebagai alat pengendalian adalah menggunakan lampu perangkap (light trap) berbagai warna (Daniar, 2016). Lampu perangkap merupakan salah satu metode yang paling umum untuk mengumpulkan serangga nokturnal (Sobiarin et.al., 2019).
Lampu perangkap merupakan alat penting untuk mengetahui populasi hama imigran guna mereduksi populasi hama dengan menangkap hama dalam jumlah besar. Pada saat ini lampu perangkap menjadi andalan komunikasi antar negara di Asia dengan dikeluarkannya perangkat lunak Asian Migratory Insects and Viruses Surveillance System (AMIVS) Asian Food and Agriculture Cooperation Initiative (AFACI)-Korea dengan negara-negara di Asia termasuk Indonesia. Setiap negara harus mengupdate data lampu perangkap dan keberadaan virus kerdil hampa dan kerdil rumput setiap hari atau paling lambat seminggu sekali, sehingga situasi hama dan 
penyakit virus di Asia (Indonesia, Thailand, Vietnam, Cambodia, Laos, Korea, Filipina, Nepal, Bangladesh) dapat diketahui oleh negara tetangga untuk antisipasi bila ada migrasi (Baihaki, 2013).

Lampu perangkap banyak digunakan untuk memantau populasi lalat (Musca domestica). Studi terbaru menyarankan lampu perangkap dapat dengan mudah ditingkatkan kinerjanya dengan menggunakan LED dengan efek positif pada desain, berat, dan daya tahan baterai. Masih sedikit informasi tentang pengaruh warna LED yang berbeda terhadap ketertarikan spesies serangga hama yang tersedia dalam literature (Gaglio et al., 2018).

Berdasarkan penelitian yang dilakukan oleh Munandar et al. (2018), tentang panjang gelombang cahaya yang dapat direspon oleh serangga berkisar antara 300-650 nm. Dimulai panjang gelombang yang paling rendah yaitu cahaya merah, kuning, ungu dan putih. Secara statistik ada perbedaan warna perangkap pohon lalat terhadap jumlah lalat yang terperangkap yang terdiri dari warna merah, kuning, ungu, putih dan hitam (kontrol).

Hakim (2016) menyatakan bahwa warna yang paling efektif menarik kehadiran serangga pada budidaya tanaman adalah warna kuning. Banyak serangga yang tertarik pada warna kuning karena adanya kemiripan warna polen bunga menjelang masak. Serangga yang dapat terperangkap antara lain wereng coklat (Nilaparvata lugens), ngengat penggerek batang padi (Scirpophaga innotata, $S$. incertulas) orong-orong/anjing tanah (Gryllotalpa sp.), kepinding tanah (Scotinophara coarctata), Coccinella sp, Paedorus sp, dan Ophionea sp.

\section{BAHAN DAN METODE}

\section{Waktu dan lokasi penelitian}

Penelitian dilaksanakan pada bulan November 2017 sampai dengan bulan Maret 2018. Tempat pelaksanaan di lahan pertanian Desa Kencong, Kabupaten Jember. Metode pengambilan data menggunakan Scan sampling, selama 11 minggu, dengan interval waktu satu minggu, dimulai jam 19.00 sampai dengan 04.00. Jumlah plot penelitian sejumlah 4 buah, masing-masing seluas $100 \mathrm{~m} 2$. jarak antar plot 100 meter. Peletakan perangkap lampu di tiap plot, secara diagonal, lima lampu perangkap LED berwarna merah, kuning, biru dan putih. Tiap warna terdiri atas 5 intensitas cahaya yaitu 3 watt, 5 watt, 7 watt dan 9 wat. Parameter pengamatan meliputi: jenis dan jumlahh serangga hama terperangkap.

Pengamatan jenis dan jumlah serangga hama terperangkap tiap jenis warna cahaya lampu perangkap LED dilakukan sejak 2 Minggu Setelah Tanam (MST) sampai 12 MST dengan interval 1 minggu, dimulai jam 19.00 s.d 04.00. Lampu diletakkan diatas corong plastik dan dibawahnya terdapat plastik transparan sehingga serangga dapat tertarik pada lampu jatuh dan terperangkap kedalam plastik. Serangga yang telah terperangkap diidentifikasi, dikelompokkan sesuai ordo, kelas, family dan spesies.

\section{Identifikasi hama}

Identifikasi serangga hama dilakukan di Laboratorium Perlindungan Tanaman Politeknik Negeri Jember, hingga tingkat Spesies dengan menggunakan buku The Pest of Crops in Indonesia (Kalshoven, 1981), Manual of Nearctic Diptera (McAlpine, 1987) dan identifikasi melalui situs (http://repository.pertanian.go.id/bitstream/handle/123 456789/9469/BROSUR\%20HAMA\%20PADI.pdf?se quence $=1 \&$ is Allowed $=\mathrm{y}$ ).

\section{Analisis statistik}

Untuk membandingkan jumlah serangga hama terperangkap antar lampu perangkap LED menggunakan Tes peringkat Kruskal-Wallis. Uji normalitas data menggunakan Tes Shapiro-Wilk. Signifikansi statistik ditentukan berdasarkan nilai $\mathrm{p}<$ 0,05 . Korelasi antara jenis warna lampu perangkap LED dengan intensitas cahaya, menggunakan uji korelasi Spearman. Data dianalisis menggunakan perangkat lunak SPSS versi 23.0.

\section{HASIL DAN PEMBAHASAN}

Jenis serangga hama terperangkap pada semua lampu perangakap LED dengan berbagai jenis warna dan intensitas cahaya terdiri atas 5 ordo, 6 famili dan 6 spesies (Tabel 1).

Tabel 1. Jenis serangga hama terperangkap pada berbagai jenis warna dan intensitas cahaya lampu perangkap LED

\begin{tabular}{lllll}
\hline No. & Ordo & Kelas & Famili & Spesies \\
\hline 1 & Hemiptera & Insekta & Alydidae & Leptocoriza acutta \\
2 & Homoptera & Insekta & Delphacidae & Nilaparvata lugens \\
3 & Homoptera & Insekta & Cicadellidae & Nepotettix virescens \\
4 & Diptera & Insekta & Cecidomyiidae & Orselia oryzae \\
5 & Lepidoptera & Insekta & Crambidae & Scirpophaga innotata \\
6 & Orthoptera & Insekta & Acrididae & Oxya chinensis \\
\hline
\end{tabular}

Jenis ordo Serangga hama yang terperangkap ialah Ordo Hemiptera, Lepidoptera, Orthoptera, Diptera dan Homoptera, terdiri atas: Walang sangit (Leptocoriza acutta). Walang sangit merupakan serangga hama terpenting pada tanaman padi (Kalshoven 1981). Kesamaan jenis serangga pada jenis warna dan intensitas cahaya lampu perangkap LED ini dapat disebabkan oleh stadia pertumbuhan, 
varietas, lokasi, teknik budidaya yang sama dan faktor abiotik yang sama. Hal ini sesuai dengan hasil penelitian Aditama dan Kurniawan (2013) tentang jenis dan struktur komunitas serangga nokturnal pada areal pertanian padi di musim penghujan menggunakan lampu perangkap, yang menyimpulkan bahwa faktor abiotik yang memiliki nilai yang tidak berbeda jauh pada setiap lokasi pengambilan sampel, menunjukkan jenis dan struktur komunitas serangga nokturnal yang sama.
Lampu perangkap LED warna cahaya merah menunjukkan jumlah tangkapan serangga hama paling tinggi. Hal tersebut menunjukkan bahwa preferensi walang sangit (Leptocoriza acutta) (Hemiptera: Alydidae) lebih menyukai warna merah (panjang gelombang pendek). Jumlah serangga hama terperangkap pada lampu perangkap LED warna cahaya merah, kuning, biru dan putih berturut turut: 475 ekor, 111 ekor, 98 ekor dan 64 ekor (Gambar 1).

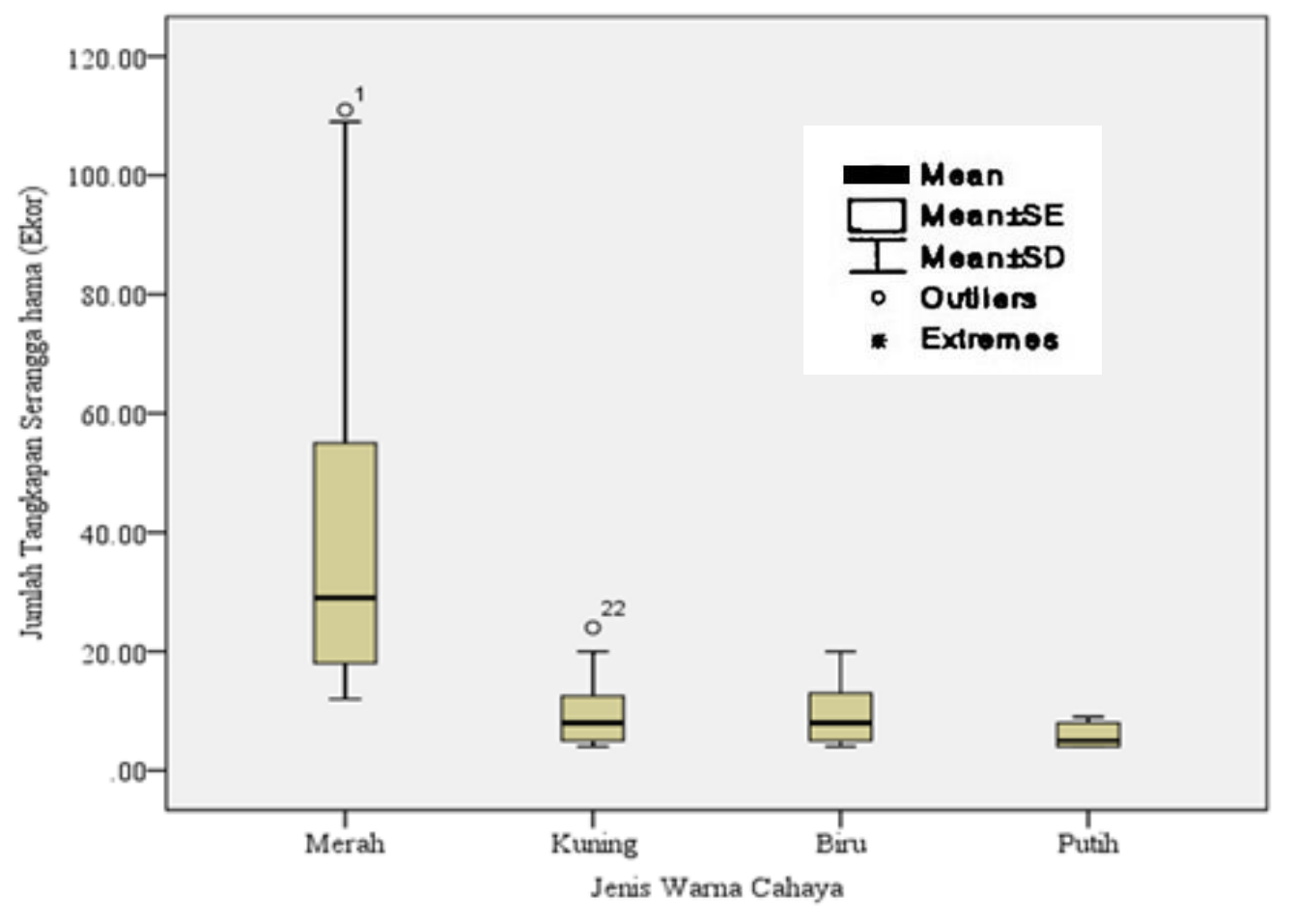

Gambar 1. Box-plot pengaruh jenis warna cahaya lampu perangkap LED terhadap jumlah tangkapan serangga hama

Berdasarkan hasil penelitian Munandar et al. (2018) bahwa lalat paling tertarik pada warna merah, kemudian pada warna putih dan terendah pada warna ungu. Sebagai implikasinya, perbedaan ketertarikan lalat terhadap warna, perangkap warna dapat digunakan untuk pengendalian lalat berdasarkan warna perangkap (Erdiansyah et al., 2018).

Intensitas cahaya lampu perangkap LED 9 Watt menunjukkan jumlah tangkapan serangga hama paling tinggi. Jumlah serangga hama terperangkap pada intensitas cahaya 3 watt, 5 Watt, 7 Watt dan 9 watt berturut-turut 366 ekor, 352 ekor, 544 ekor dan 568 ekor (Gambar 2). Hal ini dapat disebabkan serangga hama tertarik dengan intensitas cahaya yang lebih tinggi. Semakin tinggi intensitas cahaya maka serangga hama akan semakin tertarik (fototaksis positif). Berdasarkan hasil penelitian Ardiansyah dan Arawansyah (2020) menyimpulkan bahwa kemampuan perangkap hama walang sangit bergantung pada semakin bertambahnya daya dan iluminansi. Penambahan kapasita daya membuat arus semakin besar sehingga jarak pencaran cahaya semakin jauh, medan cahaya yang terpancar sebagai pemicu bagi serangga untuk mendekati sumber cahaya.

Korelasi antara panjang gelombang warna Lampu perangkap LED dan intensits cahaya dianalisis menggunakan uji korelasi bivariat Spearman. Hasil uji korelasi Spearman bahwa korelasi antara jenis warna cahaya lampu perangkap LED dan intensitas cahaya menunjukkan korelasi negatif $(p<0,05)$. Hal ini menunjukkan bahwa jika jumlah tangkapan serangga hama yang tinggi pada warna cahaya lampu perangkap yang memiliki panjang gelombang rendah, diperlukan intensitas cahaya lampu perangkap LED yang lebih tinggi, demikian sebaliknya. Koefisien korelasi antara warna cahaya lampu perangkap LED dan intensitas cahaya dalam penelitian ini tergolong berkorelasi cukup dan negatif $(r)=-0,415$. 


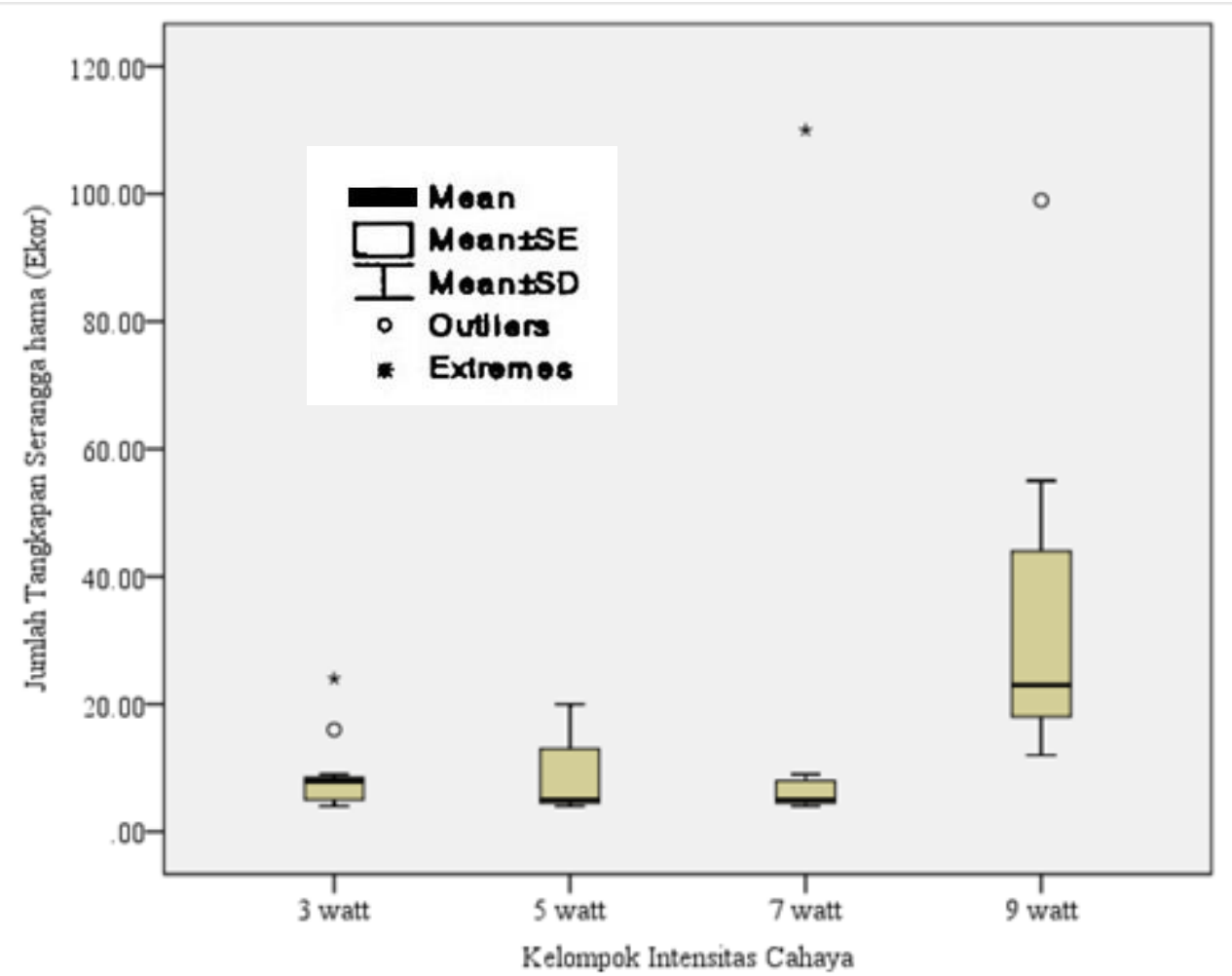

Gambar 2. Box-plot pengaruh intensitas cahaya lampu perangkap LED terhadap jumlah tangkapan serangga hama

\section{KESIMPULAN DAN SARAN}

Kesimpulan penelitian ini sebagai berikut:

1. Jenis serangga hama padi yang terperangkap pada berbagai jenis warna cahaya dan intensitas cahaya perangkap lampu LED menunjukkan kesamaan, terdiri atas 5 ordo, 6 famili dan 6 spesies yaitu Leptocoriza acutta, Nilaparvata lugens, Nepotettix virescens, Orselia oryzae, Scirpophaga innotata dan Oxya chinensis.

2. Lampu perangkap LED warna cahaya merah dapat memerangkap serangga hama paling tinggi. Jumlah serangga hama terperangkap pada lampu perangkap LED warna merah, kuning, biru dan putih berturut turut: 475 ekor, 111 ekor, 98 ekor dan 64 ekor.

3. Lampu perangkap LED 9 Watt dapat memerangkap serangga hama paling tinggi. Jumlah serangga hama terperangkap pada intensitas cahaya 3 watt, 5 Watt, 7 Watt dan 9 watt berturut-turut 366 ekor, 352 ekor, 544 ekor dan 568 ekor.

4. Koefisien korelasi antara jenis warna cahaya lampu perangkap LED dan intensitas cahaya yaitu (r) $=-0,415$ (berkorelasi negatif, kategori berkorelasi cukup).

\section{DAFTAR PUSTAKA}

Aditama RC, \& Kurniawan N. 2013. Struktur Komunitas Serangga Nokturnal Areal Pertanian Padi Organik pada MusimPenghujan di Kecamatan Lawang,
Kabupaten Malang. Jurnal Biotropika . 1 (4): 186-190

https://biotropika.ub.ac.id/index.php/biotropi ka/article/view/177/150.

Ardiansyah, \& Arawansyah. 2020. Desain Dan Realisasi Perangkap Hama Walangsangit (Phw) Berbasis Cahaya Lampu. Program Studi Teknik Elektro Fakultas Teknik Universitas Muhammadiyah Makassar (Skripsi). https://digilibadmin.unismuh.ac.id/upload/10 475-Full_Text.pdf

Baehaki SE. 2013. Hama Penggerek Batang Padi dan Teknologi Pengendalian. Iptek Tanaman Pangan 8 (1): 1-14 http://ejurnal.litbang. pertanian.go.id/index.php/ippan/article/view/ $2553 / 2193$

Daniar PR. 2016. Pengaruh Perbedaan Warna Perangkap Lampu Light Emitting Diode (LED) Sebagai Monitoring Hama Scirpophaga innotata Pada Pertanaman Padi. Skripsi Sarjana, Universitas Brawijaya. http://repository.ub.ac.id/131540/.

Erdiansyah, Mayasari I, Putri FSU, \& Kartikasari V. 2018. Full trap method in handling warehouse pests in ledokombo, Jember. IOP Conference Series: Earth and Environmental Science. IOP Conf. Ser.: Earth Environ. Sci. 207 012040. https://iopscience.iop.org/ article/10.1088/1755-1315/207/1/012040/ meta. 
Gaglio G, Napoli ENF, Arfuso F, Abbate JM, Giannetto S, \& Brianti E. 2018. Do Different LED Colours Influence Sand Fly Collection by Light Trap in the Mediterranean? Hindawi BioMed Research International. Volume 2018, Article ID 6432637, 7 pages https://downloads.hindawi.com/journals/bmri /2018/6432637.pdf

Sobiatin E, Khosiyatun N, Herianto \& Kuswanto H. 2019. The Effect of Light Color Variation in Simple Light Traps on the Number of Fruit Flies (Bactrocera sp.). Planta Tropika: Jurnal Agrosains (Journal of Agro Science) 7(2): 147-153https://journal.umy.ac.id/index. $\mathrm{php} / \mathrm{pt} / \mathrm{article} / \mathrm{view} / 6289 / 5197$.

Hakim L, Surya E, \& Muis A. 2016. Pengendalian Alternatif Hama Serangga Sayuran dengan Menggunakan Perangkap Kertas. Jurnal Agro, 3(2), pp.21-33. https://www.research
gate.net/publication/313231180_Pengendalia n_Alternatif_Hama_Serangga_Sayuran_deng an_Menggunakan_Perangkap_Kertas.

Kalshoven LGE. 1981. The Pests of Crops in Indonesia. Jakarta: Ichtiar Baru.

McAlpine JFB, Peterson V, Shewell GE, Teskey HJ, Vockeroth JR, \& Wood DM. 1987. Manual of Nearctic Diptera Volume 1. Ottawa: Research Branch Agriculture Canada. http://www.online-keys.net/sciaroidea/add01/ McAlpine_et_al_1981_9_Morphology.pdf

Munandar MA, Retno H, \& Nissa K. 2018 Perbedaan Warna Perangkap Pohon Lalat Terhadap Jumlah Lalat Yang Terperangkap Ditempat Pembuangan Akhir (TPA) Sampah Jatibarang Kota Semarang. Jurnal Kesehatan Masyarakat (e-Journal) Volume 6, Nomor 4, Agustus 2018. https://ejournal3.undip.ac.id/ index.php/jkm/article/view/21388/19884. 